DOI https://doi.org/10.30525/978-9934-26-047-6-10

\title{
ТЕХНОЛОГІЇ ВИРОЩУВАННЯ, ДІЕТИЧНІ ВЛАСТИВОСТІ І КУЛІНАРНЕ ЗАСТОСУВАННЯ ВИНОГРАДНИХ РАВЛИКІВ НЕLIX ASPERSA MULLER
}

\author{
Шевченко I. B. \\ учитель-методист, учитель біології \\ Комунального закладу «Харківський науковий ліией-інтернат \\ «Обдарованість»» Харківської обласної ради
}

\author{
Скала Б. М. \\ учень 9 класу
}

Комунального закладу «Харківський науковий ліцей-інтернат

"Обдарованість"» Харківської обласної ради

м. Харків, Україна

В результаті неповноцінного харчування в Україні протягом 1995-2018 рр. вдвічі зросла захворюваність населення на ендокринні хвороби, розлади харчування та порушення обміну речовин, спостерігається тенденція до набирання зайвої маси тіла та поширення ожиріння [3, с .101]. Тому головним завданням $€$ пошук альтернативних натуральних дієтичних продуктів для забезпечення здорового харчування [1, с. 24]. Для свого дослідження ми взяли незвичний для України продукт - виноградних равликів (Helix aspersa muller).

Мета дослідження полягає у всебічному опрацюванні теоретичних та практичних аспектів розвитку здорового харчування равликами, ознайомлення споживачів з новим видом білку. У процесі дослідження одержано результати, що мають елементи наукової новизни: обгрунтовано дієтичні властивості равликового м'яса та доцільність розвитку власної равликової ферми. Якщо порівняти санітарно-гігієнічні показники м'яса, яке отримали від слимаків, з м'ясом птиці чи жуйних тварин, то за більшістю показників воно є кращим. Равлики також користуються підвищеним попитом в медицині, оскільки є відмінною сировиною для створення величезного списку лікарських препаратів. В останні роки лікарі й косметологи використовують препарати слизу у складі кремів, лосьйонів та аерозолів. За рахунок високого вмісту біологічно-активних речовин, ці препарати сприяють швидкому загоюванню ран, регенерації шкіри, збереженню іiі еластичності й 
запобіганню утворенню зморшок. На сучасному етапі в Україні формується нова перспективна галузь тваринництва, розвиток якої вже найближчими роками призведе до зростання експортних поставок равликів та продуктів їх переробки до країн Європи. Велика частина територій України має сприятливі кліматичні умови для вирощування їстівних равликів, тому це відмінна ідея для тих, хто хоче відкрити бізнес в сільському господарстві з нуля.

Існує декілька видів їстівних равликів. Найбільш популярними Helix aspersa maxsima та Helix aspersa muller [2, с. 216]. Равлики не вибагливі до якості грунту, тому фермери обрали звичайну присадибну ділянку. Вони побудували вольєр, щоб равлики жили саме на цій ділянці, а не по всьому городу. Фермери засіяли ділянку культурою перко. Перко харчуються маленькі равлики, які ще не спроможні засвоювати збалансований спеціальний корм. Равликів запустили на поле у середині травня, коли перко зросла на 15-20 см . Розмір маленького равлика був близько 0,4 см. Наприкінці червня ми відвідали равликову ферму вдруге. Равлики Helix aspersa muller вже були більшого розміру. Фермери розташували на ділянці спеціальні щити (піддони), які були вироблені із дерева. Вдень равлики сплять, так як вони ведуть нічний спосіб життя. Вдень щити слугують для укриття від пекельного сонця, а вночі для подачі іжі. Втретє ми відвідали ферму у вересні. Вже сформованих равликів почали збирати та розміщувати у сітки. Ми зважили вже зрощеного равлика. Вага дорослого равлика складала 1,10-1,20 г. Сітка 3 равликами важила 4-5 кг. Равликів ретельно промивали водою та висушували. Після збору, равликів необхідно витримати у голоді і промивати водою, для того щоб позбутися слизу. Після того, як їх ретельно висушили, сітки складали у спеціальні холодильні камери 3 температурою $4^{\circ} \mathrm{C}$. Равлики впадають у стан гібернації (стан зимової сплячки). Так вони можуть спати 8 місяців. Вирощування равликів тривало з травня по вересень [3]. Другим етапом дослідження особливостей утримування равлика виноградного було підбір найбільш оптимального раціону харчування, ми взяли два різновиди корму. Першу групу равликів ми годували свіжою рослинною їжею: капуста, морква, огірки, кабачок. Другу групу - годували спеціальним комбікормом, до складу якого входять 7 різних злаків та кальцій. Таким чином, для проведення експерименту ми маємо два різновиди кормів: корм № 1 - свіжі овочі; корм № 2 - комбікорм. Період проведення дослідження -4 місяці. Кількість 
досліджуваних равликів - 10 штук (по 5 штук для кожного виду корму).

\section{Дослідження розмірів равлика виноградного} в залежності від типу харчування

\begin{tabular}{|c|c|c|c|c|}
\hline $\begin{array}{c}\text { Дата } \\
\text { проведення } \\
\text { замірів }\end{array}$ & $\begin{array}{c}\text { Довжина } \\
\text { черепашки } \\
\text { равлика, } \\
\text { корм №1, } \\
\text { см }\end{array}$ & $\begin{array}{c}\text { Середнє } \\
\text { значення, } \\
\text { см }\end{array}$ & $\begin{array}{c}\text { Довжина } \\
\text { черепашки } \\
\text { равлика, } \\
\text { корм №2, } \\
\text { см }\end{array}$ & $\begin{array}{c}\text { Середнє } \\
\text { значення, } \\
\text { см }\end{array}$ \\
\hline \multirow{5}{*}{17.06 .2020} & 1,7 & \multirow{5}{*}{1,7} & 1,5 & \multirow{5}{*}{1,6} \\
\hline & 1,5 & & 1,6 & \\
\hline & 1,8 & & 1,5 & \\
\hline & 1,6 & & 1,7 & \\
\hline & 1,7 & & 1,5 & \\
\hline \multirow{5}{*}{15.10 .2020} & 2,8 & \multirow{5}{*}{2,9} & 3,0 & \multirow{5}{*}{3,1} \\
\hline & 3,2 & & 3,1 & \\
\hline & 3,0 & & 3,0 & \\
\hline & 2,7 & & 3,0 & \\
\hline & 3,0 & & 3,2 & \\
\hline
\end{tabular}

Згідно отриманих результатів наведених у таблиці можна зробити висновок, що харчування кормом № 2 (комбікорм) прискорює ріст., оскільки він містить всі необхідні для здоров'я равлики мікро- i макроелементи. При цьому корм додатково збагачений вітамінами для додаткового зростання і зміцнення раковини.

Порівняння масової частки хімічних речовин різних видів м'яса

\begin{tabular}{|c|c|c|c|c|}
\hline \multirow[b]{2}{*}{ М'ясо } & \multicolumn{3}{|c|}{ Вміст, г на 100 г їстівної частини } & \multirow{2}{*}{$\begin{array}{c}\text { Енергетична } \\
\text { цінність, } \\
\text { кДж }\end{array}$} \\
\hline & води & білка & жиру & \\
\hline Равлики & 84,4 & 14,8 & 1,6 & 366 \\
\hline Яловичина & 67,7 & 18,9 & 12,4 & 782 \\
\hline Баранина & 67,7 & 16,3 & 15,3 & 849 \\
\hline Свинина & 51,6 & 11,6 & 33,0 & 1485 \\
\hline Кури & 61,9 & 18,2 & 18,1 & 1008 \\
\hline
\end{tabular}


За результатами порівняння хімічних показників різних видів м'яса робимо висновок, що м'ясо равлика виноградного відрізняється від інших видів м'яса високим вмістом білка і низьким вмістом жирів.

Теоретичне та практичне значення наукового дослідження полягає в тому, що: результати дослідження можуть бути використані у якості рекомендацій споживання равликового м'яса, як альтернативного продукту дієтичного харчування; може бути теоретичними порадами щодо створення власної равликової ферми; сприятиме формуванню культури споживання страв із равликів. Розведення виноградних равликів в домашніх умовах - це прибутковий бізнес, про який мало хто знає і який зможе принести масу задоволення і хороший дохід.

\section{Література:}

1. Банковська Н.В. Гігієнічна оцінка стану фактичного харчування дорослого населення України та наукове обгрунтування шляхів його оптимізації. Автореф. дис. канд. мед. наук: 14.02.01, К.: Нац. мед. ун-т ім. О.О. Богомольця, 2018, 24 с.

2. Гураль-Сверлова Н.В., Гураль Р.І. Визначник наземних молюсків України. Львів. 2012. 216 с.

3. Швець О.В., Салій Н.С., Цимбаліст О.В. [та ін.]. Вивчення стану фактичного харчування та його зв'язок із аліментарною захворюваністю дорослого населення 4-х областей України 3 метою його раціоналізації. Звіт про НДР. - Київ, ДП «Державний науково-дослідний центр з проблем гігієни харчування», 2016, 101 с. 